Research Article

\title{
A calm look at the cost of various brands of antiasthmatic drugs available in India
}

\author{
Shakeel Ahmad Mir*
}

Department of Clinical Pharmacology, Sher-I-Kashmir Institute of Medical Sciences (SKIMS), Soura, Kashmir, India

Received: 26 December 2015

Accepted: 18 January 2016

\section{*Correspondence to:}

Dr. Shakeel Ahmad Mir, Email: drshakeelahmadmir @gmail.com

Copyright: (C) the author(s), publisher and licensee Medip Academy. This is an openaccess article distributed under the terms of the Creative Commons Attribution NonCommercial License, which permits unrestricted noncommercial use, distribution, and reproduction in any medium, provided the original work is properly cited.

\begin{abstract}
Background: Asthma is an inflammatory disorder of lungs that affects people of all ages and is a significant source of morbidity and mortality worldwide. Approximately 300 million people in the world currently have asthma and there has been a concerning increases in the prevalence of this condition in recent decades. The asthma epidemic experienced by high-income countries over the past 30 years is now an increasing problem in low- and middle-income countries. Because asthma is a chronic condition, it requires continuous medical care. Failure to use appropriate drugs and comply with treatment can lead to unnecessary deaths. Higher and unaffordable drug prices are among the major reasons for non-compliance and resultant treatment failure. In the global market, the cost of drugs is highly variable. The cost of drugs plays a crucial role in patient's care especially in developing countries. It has been observed that there is a gross variation in the cost of different brands of same generic drug. If doctors are not aware that large differences can exist in the price of medications used for the same indication, they may prescribe costly brands, which ultimately lead to non-adherence. The present study was planned to get some idea about cost differences in various brands of antiasthmatic drugs.

Methods: The minimum and the maximum cost in Rupees (INR) of a particular antiasthmatic agent manufactured by various pharmaceutical companies in the same strength were noted. The cost ratio and percentage cost variation were noted for each brand.

Results: This study shows that there is a noticeable variation in the prices of different brands of same antiasthmatic drug in Indian market. The highest percent cost variation (663) was found for Deflazacort 6mg tablet, followed (404) for Doxophylline $400 \mathrm{mg}$ tab. Other significant percent cost variations were for: Theophylline $600 \mathrm{mg}$ tab (353), Combination of Formoterol and Budesonide (122), Budesonide (103), Monteleukast $10 \mathrm{mg}$ tab (93) and Deflazacort $1 \mathrm{mg}$ (88). The lowest percent cost variations found were for: Monteleukast 4mg tab (10), Ipratropium bromide (14) and Monteleukast 5mg tab (20).

Conclusions: Since there is a significant cost variation in different brands of the same generic antiasthmatic drug, a conscientious doctor should always choose cheapest effective brand while prescribing. Asthma being a chronic illness requiring prolonged treatment, even a small cost variation can have significant economical implications.
\end{abstract}

Keywords: Cost analysis, Antiasthmatic, Compliance, Adherence, Branded drugs, Asthma, Health economics

\section{INTRODUCTION}

Asthma is a serious global health problem affecting all age groups, with increasing prevalence in many developing countries. It affects an estimated 300 million individuals worldwide. ${ }^{1}$ Worldwide deaths from this condition have reached over 180,000 annually. India has an estimated 15-20 million asthmatics. ${ }^{2}$ Asthma is associated with enormous healthcare expenditures that includes both direct costs, in the form of hospitalizations and medications, and indirect costs, in the form of loss of work which is a combination of directly missed days of 
work/school that occur during the exacerbation and the loss of future potential earnings associated with both morbidity and mortality. ${ }^{3}$ Asthma imposes an unacceptable burden on healthcare systems, and on society through loss of productivity in the workplace and, especially for pediatric asthma, disruption to the family. ${ }^{1}$ Asthma is a serious burden in low- and middle-income countries. ${ }^{4}$ The economic costs associated with asthma are estimated to rank as one of the highest among chronic diseases due to the significant healthcare utilization associated with this condition. ${ }^{3}$ Worldwide, these costs are estimated to exceed those of TB and HIV/AIDS combined. Because asthma is a chronic condition, it usually requires continuous medical care. Failure to use appropriate drugs or comply with treatment can lead to unnecessary deaths. ${ }^{2}$

Expenditure on medicines accounts for a major proportion of health costs in developing countries. The access to treatment is heavily dependent on the availability of affordable medicines. ${ }^{5}$ The consideration of cost of treatment for ailments is an important aspect in health economics. ${ }^{6}$ Modern management of bronchial asthma mandates prolonged medication. A key issue in the management of bronchial asthma is adherence (compliance) to treatment. ${ }^{7}$ Cost related poor patient compliance is a worldwide problem. Poor or noncompliance affects clinical outcome and increases healthcare costs. ${ }^{8}$ Several surveys on retail prices of drugs have been carried out and published. All these studies have reported wide variations in the retail prices of drugs. ${ }^{9}$

The present study was aimed at investigating the acquisition cost differences in various brands of same generic antiasthmatic drug, so that whenever possible, a cheaper effective brand can be prescribed to ensure better compliance and reduce drug cost as well as total healthcare costs. Better patient compliance will also reduce morbidity and mortality.

\section{METHODS}

Prices of various antiasthmatic drugs were obtained from the latest issue of drug today ${ }^{10}$, CIMS $^{11}$, and online site "drug brands". 12

1. The minimum and the maximum cost in Rupees (INR) of a particular antiasthmatic drug manufactured by various pharmaceutical companies in the same strength were noted.

2. The cost ratio, the ratio of the cost of the costliest to cheapest brand of the same generic antiasthmatic was calculated. This tells, how many times costliest brand costs more than the cheapest one in each generic group.

3. Percentage cost variation was calculated as follows: ${ }^{13}$

$\%$ cost variation $=\frac{\text { Maximum } \operatorname{cost}-\text { minimum } \operatorname{cost}}{\text { Minimum } \operatorname{cost}} \times 100$

\section{RESULTS}

This study shows that there is a noticeable variation in the prices of different brands of same antiasthamatic drug in Indian market. The highest percent cost variation (663) was found for Deflazacort 6mg tablet, followed (404) for Doxophylline $400 \mathrm{mg}$ tab. Other significant percent cost variations were: Theophylline $600 \mathrm{mg} \operatorname{tab}(353)$, Combination of Formoterol and Budesonide (122),Budesonide (103), Monteleukast $10 \mathrm{mg}$ tab (93) and Deflazacort $1 \mathrm{mg}$ (88). The lowest percent cost variations found were: Monteleukast $4 \mathrm{mg}$ tab (10), Ipratropium bromide (14) and Monteleukast 5mg tab (20) (Table 1).

\section{DISCUSSION}

It has been estimated that over two billion people in developing countries have no access to drugs. They lack access because prices are high and their purchasing power is low. ${ }^{9}$ According to Planning Commission of India report (2014), 363 million people were below poverty line in 2011-12 in India, accounting for $29.5 \%$ of total population of the country. ${ }^{14}$ People purchase the amount of drug they can afford and not what they need to be cured for. ${ }^{15}$ For below poverty line people, cost of the drugs is a very important factor. In a large survey significant percentage of even high income respondents indicated cost of the drugs as an important factor. ${ }^{16}$ Acquisition cost (medicine price) is one of the most important aspects in calculating health-care costs, though it is only a start in total evaluation. ${ }^{17}$ One of the important factors contributing to poor patient compliance is the cost of the drugs. ${ }^{18}$

Poor patient compliance is a worldwide problem and can result in patients receiving inappropriate doses of medication. $^{8}$

A new Harris Interactive Survey shows that as a direct result of the high out-of-pocket cost of drugs, millions of the people do not ask the doctors for the prescription they need, do not refill the prescriptions they are given, use lower doses of drugs than they are prescribed and take their drugs less often than they should. The higher the people`s out-of-pocket cost of drugs, the more likely they are to be non-compliant. In this survey it was found that with out-of -pocket costs of $\$ 500$ a year, $44 \%$ patients do not refill the prescription, $41 \%$ use a lower dose to make prescription last longer and $46 \%$ use a drug less often than prescribed to make it last longer. ${ }^{19}$

Being a chronic medical condition, management of asthma requires continuous medical care. A key issue with the proper management of asthma is adherence to treatment. $^{7}$ In this study noticeable cost variation was found in different brands of same generic antiasthmatic drug. Similar findings have been reported from different studies conducted in India., ${ }^{6,13,20}$ The cost difference calculated in this study was for a course of drug sufficient 
for a maximum period of one month. The cost variation assumes more significance in chronic diseases like asthma, which require prolonged treatment. Even a minor cost variation between different brands of same antiasthmatic drug will have serious financial implications, as asthma requires prolonged medical care.

Table 1: Cost analysis of different antiasthmatic drugs.

\begin{tabular}{|c|c|c|c|c|c|}
\hline Group/Drug & Strength & $\begin{array}{l}\text { Min } \\
\text { cost(INR) }\end{array}$ & Max cost(INR) & cost ratio & $\begin{array}{l}\% \text { cost } \\
\text { variation }\end{array}$ \\
\hline \multicolumn{6}{|l|}{$\beta_{2}$-agonists } \\
\hline Salmeterol & 50mcg (30 caps) & 40 & 62.50 & $1: 1.6$ & 56 \\
\hline Formoterol & $12 \mathrm{mcg}(120 \mathrm{mdi})$ & 110 & 142 & $1: 1.3$ & 29 \\
\hline Bambuterol & $10 \mathrm{mg}(10 \mathrm{tab})$ & 29 & 48 & $1: 1.6$ & 65 \\
\hline \multicolumn{6}{|c|}{ Anticholinergics } \\
\hline Ipratropium & $200 \mathrm{mcg}(200 \mathrm{mdi}$ & 125 & 142.80 & $1: 1.1$ & 14 \\
\hline Tiotropium & $18 m c g$ (15 caps) & 133.30 & 149 & $1: 1.1$ & 12 \\
\hline \multicolumn{6}{|c|}{ Methylxanthines } \\
\hline Theophylline & $600 \mathrm{mg}$ (10 tabs) & 9.23 & 41.85 & $1: 4.5$ & 353 \\
\hline Doxophylline & 400mg (10 tabs) & 15.85 & 80 & $1: 5.0$ & 404 \\
\hline \multicolumn{6}{|c|}{ Corticosteroids } \\
\hline Budesonide & 100mcg (10 cap) & 15 & 30.50 & $1: 2.0$ & 103 \\
\hline Fluticasone & 100mcg (30 cap) & 90 & 135 & $1: 1.5$ & 50 \\
\hline Ciclesonide & 120mdi & 281.11 & 358.56 & $1: 1.3$ & 28 \\
\hline \multicolumn{6}{|c|}{ Mast cell stabilizers } \\
\hline Cromolyn & 20mg (30 cap) & 60.40 & 96.48 & $1: 1.6$ & 60 \\
\hline \multicolumn{6}{|c|}{ Leukotriene modulators } \\
\hline \multirow[t]{3}{*}{ Monteleukast } & $4 \mathrm{mg}(10 \mathrm{tab})$ & 63.40 & 89.18 & $1: 1.4$ & 10 \\
\hline & $5 \mathrm{mg}(10 \mathrm{tab})$ & 81.50 & 98.30 & $1: 1.2$ & 20 \\
\hline & $10 \mathrm{mg}(10 \mathrm{tab})$ & 92.40 & 178.56 & $1: 1.9$ & 93 \\
\hline \multicolumn{6}{|l|}{ Combinations } \\
\hline $\begin{array}{l}\text { Salmeterol + } \\
\text { Fluticasone }\end{array}$ & $\begin{array}{l}50+100 \mathrm{mcg}(30 \\
\text { cap) }\end{array}$ & 98 & 119 & $1: 1.2$ & 21 \\
\hline $\begin{array}{l}\text { Formoterol + } \\
\text { Budesonide }\end{array}$ & $\begin{array}{l}6+200 \mathrm{mcg}(120 \\
\text { mdi) }\end{array}$ & 175 & 389 & $1: 2.2$ & 122 \\
\hline $\begin{array}{l}\text { Ipratropium + } \\
\text { Salbutamol }\end{array}$ & $\begin{array}{l}20+200 \mathrm{mcg}(200 \\
\mathrm{mdi})\end{array}$ & 170.37 & 210 & $1: 1.2$ & 23 \\
\hline $\begin{array}{l}\text { Bambuterol + } \\
\text { Monteleukast }\end{array}$ & $\begin{array}{l}\text { 10mg+10mg (10 } \\
\text { tabs) }\end{array}$ & 142 & 161.80 & $1: 1.1$ & 14 \\
\hline
\end{tabular}

Doctor's ignorance of costs, combined with their tendency to underestimate the price of expensive drugs and overestimate the price of inexpensive ones, demonstrate a lack of appreciation of the large difference in cost between inexpensive and expensive drugs. This discrepancy in turn could have profound implications for overall drug expenditures. ${ }^{21}$ Many medicines are very expensive and there are often equally effective brands available for treating the same condition. In India most of the drugs are available in brands and they are also prescribed by clinicians mostly by brand name. This may affect the patients finance adversely if costly brand is prescribed especially in diseases like asthma that needs treatment for longer duration. Prescribing a costlier brand can result in non-compliance which leads to treatment failure and may even necessitate hospital admissions. ${ }^{8}$ If a doctor prescribes the cheaper effective brand it could result in savings for whoever is paying for the drug, be it the government, the patient or a medical insurance organization.

\section{CONCLUSION}

Direct costs of asthma have been shown to exceed indirect costs and the major component of direct medical costs includes pharmacological expenditures. Many studies have found that the drug cost of asthma accounted for the greatest part (53-100\%) of the overall cost. In the present study, the costs of some antiasthmatic drugs were found highly variable. Governments should ensure that antiasthmatic drugs are available, quality assured and affordable for everyone. Doctors must prescribe 
rationally. Rational prescribing means choosing costeffective and safe medicines based on country`s health situation.

\section{Funding: No funding sources}

Conflict of interest: None declared

Ethical approval: Not required

\section{REFERENCES}

1. Global Initiative for Asthma (GINA): Pocket guide for asthma management and prevention. Available at http://www.ginasthma.org/local/uploads/files/GINA_ Pocket_2015.pdf. Accessed on 16.12.2015.

2. World Health Organization. Fact sheet $\left(\mathrm{N}^{0} 206\right)$ : Bronchial asthma. Available at http://www.who.int/mediacentre/factsheets/fs206/en/ Accessed on 16.12.2015.

3. Bahadori K, Doyle-Waters MM, Marra C, Lynd L, Alasaly K, Swiston J. Economic burden of asthma: a systematic review. BMC Pulm Med. 2009;19;9:24.

4. Global Asthma Network: The Global Asthma Report 2014.http://www.globalasthmareport.org/resources/G lobal_Asthma_Report_2014.pdf. Accessed on 16.12.2015.

5. World Health Organization. Trade, foreign policy, diplomacy and health: Access to medicine. Available at http://www.who.int/trade/glossary/story002/en/ Accessed on 16.12.2015.

6. Gupta RK, Reddy PS. A calm look on cost analysis of different brands of anti-epileptic drug. J MGIMS. 2011;16(i):64-6.

7. Bhushan B, Gaude G. Study to assess factors contributing to compliance of aerosol therapy in bronchial asthma. Internet $\mathbf{J}$ Pulm Med. 2009;12(1):1-6.

8. Kardas P, Bishai WR. Compliance in infective medicine. Adv Stud Med. 2006;6(7C):S652-8.

9. World Health Organization: Workshop on differential pricing and financing of Essential Drugs. https://www.wto.org/english/tratop_e/trips_e/hosbjor _presentations_e/35balasubramaniam_e.doc Accessed on 16.12 .2015 .

10. Drug Today. October-December. 2015;23(2):867-89.

11. CIMS. 2015(update 3):130-60.
12. Drug Brands: available at http://drugbrands.in/index.php?/. Accessed on 16.12.2015.

13. Akila L, Rani RJ. Cost analysis of different brands of antianginal drugs available in India. Int J Basic Clin Pharmacol. 2015;4:860-3.

14. Planning Commission Govt. of India 2014. Report of the expert group to review the methodology for measurement of poverty. Available at http://planningcommission.nic.in/reports/genrep/pov _rep0707.pdf. Accessed 12.12.2015.

15. Uppsala universitet. Economical access to antibiotics in an era of increasing resistance - a study from Lahore, Pakistan (CR). Available at http://www.farmfak.uu.se/farm/exjob/diplomawork/ VT10BinaAzhar.pdf. Accessed 12.12.2015.

16. Piette JD, Beard A, Rosland AM, McHorney CA. Beliefs that influence cost-related medication nonadherence among the "haves" and "have nots" with chronic diseases. Patient Prefer Adherence. 2011;5:389-96.

17. Management Sciences for Health (MSH). Evaluating the cost of pharmaceuticals. 2007. Available at http://www.who.int/medicines/technical_briefing/tbs /06-TG_Evaluating-drug-costs_final-08.pdf. Accessed 12.12.2015.

18. SCOPE: Pharmacist's Guide to Judicious Usage of Antibiotics.https://cme.dannemiller.com/scope/articl es/activity?id=428\&p=12. Accessed 12.12.2015.

19. PR Newswire: Higher Out-of-Pocket Costs Cause Massive Non-Compliance in the Use of Prescription Drugs, and This Is Likely to Grow. Available at http://goo.gl/2CIISI. Accessed 16.12.2015.

20. Andayani TM, Imaningsih I. Cost analysis of antidiabetic drugs for diabetes mellitus out patient in Kodya Yogyakarta hospital. Malay J pharm Sci. 2007;5(1):19-23.

21. Allan GM, Lexchin J, Wiebe N. Physician awareness of drug cost: A systematic review. PLoS Med. 2007;4(9):e283.

Cite this article as: Mir SA. A calm look at the cost of various brands of antiasthmatic drugs available in India. Int J Basic Clin Pharmacol 2016;5:142-5. 